Published on Reviews in History (https://reviews.history.ac.uk)

\title{
The Cry of the Renegade: Politics and Poetry in Interwar Chile
}

Review Number: 2128

Publish date: Thursday, 29 June, 2017

Author: Raymond Craib

ISBN: 9780190241353

Date of Publication: 2016

Price: $£ 22.99$

Pages: 288pp.

Publisher: Oxford University Press

Publisher url: https://global.oup.com/academic/product/the-cry-of-the-renegade-9780190241353?cc=gb\&lang=en\&

Place of Publication: Oxford

Reviewer: Camila Gatica

The Cry of the Renegade begins with the ending of the story. The book starts by mapping the procession that took place on 1 October 1920, when thousands took to the streets to pay their respects and say farewell to José Domingo Gómez Rojas, a poet, university student, and municipal clerk. In his narrative of the procession, Raymond B. Craib suggests that the route the funeral followed represented a succession of symbolic spaces. Symbolic not only for one group of people, but for many. This book presents a study of the different representations of space and people during a four-month period in 1920 (July-October), which in fact reflects on the wider state of 1920s Chile. This review will attempt to tackle the main ideas developed by Craib.

Craib sees Gómez Rojas's death as the culmination of a process of repression that had started four months before. Although the book begins and ends with the story of Gómez Rojas, Craib uses the poet as a way into the world of university and working class politics and culture. By looking at the months between Gómez Rojas' arrest and his death, the book attempts to provide a microhistory approach to the 1920s Chile, but particularly a view of Santiago. Through the study of a few cases (each chapter focuses on different aspects and people considered 'subversives'), Craib is able to discuss the experience of a group of men who were friends and comrades; as well as the experience of aristocrats, prosecutors, and policing institutions. In this sense, this book is also about the structural violence that existed (and still exists) in Chile's unequal system: 'the violence of the state, of capitalism, and of the wage system' (p. 7). This is one of the strongest aspects of Craib's work, as one is able to link it to problems that are still present in Chilean society, rendering the study not only necessary, but current.

The book is divided into four chapters, each of them tackling different aspects of the life of poets, writers and activists considered subversives in inter-war Chile. Chapter one starts with a brief narrative of 19 July 1920, when Chilean authorities expelled Casimiro Barrios Fernández. The chapter focuses on him, and how he came to make a life for himself in Santiago. This chapter allows Craib to put forward the idea that the radicals the book focuses on were sedentary. This meant that, although they saw themselves as citizens of the world, they had found a place for themselves, they had settled and developed roots. Casimiro Barrios, Spaniard by birth, had been living in Chile since he was 14 years old, had married a Chilean and started a family in Santiago. Moreover, these sedentary radicals presented challenges to the authorities because they 
defied pre-conceived ideas of radicals as foreign agitators. Futhermore, these sedentary agitators had the knowledge of labour laws to confront employers, making them more dangerous in their eyes.

Chapter two focuses on the brothers Gandulfo. It also begins by telling a brief anecdote from 19 July 1920, about how a group of young people from prominent families of Santiago (the so-called golden youth) went looking for Juan Gandulfo. They were after him because they considered him and his friends to be traitors based on the ideas they supported, ideas which went against mobilising the military reserves in order to respond to threats from Peru, an order issued by President Sanfuentes. This chapter tells the story of how Universidad de Chile expanded enrolment, which affected how student politics changed in the 1920s. In this context, the Chilean Student Federation (FECh) became more than a space for students to meet, reshaping the role of the federation and of the people who were part of it. This new way of being political also reshaped the space and the streets of the city, turning them into places which both students and workers could appropriate and make their own. These became the new spaces where politics were developing, where 'political and social solidarity was both possible and real' (p. 71). This type of politics also re-signified the urban space. However, the main question this chapter poses is about who constitutes the internal enemy: was it the golden youth and its violent reaction towards FECh and those involved in it, or was it those considered to have subversive and anti-patriotic ideas?

The third chapter sets out by describing how Manuel Alejandro Covarrubias Ortúzar, the son of an unconditional Conservative party supporter, ended up dead. A group of young men (of which Covarrubias was part) were celebrating the attacks on the FECh by roaming the streets looking for anti-patriots. The idea was to force them to kiss the flag as a way of demonstrating their submission to the country. Everything went wrong when they tried to force a young locksmith to kiss the flag, who in turn did not like the demanding tone in which he was asked to do this and refused. As a reaction, shots were fired and Covarrubias, who was one of the flag bearers, was hit and died. By beginning the chapter with this event, Craib sets out to explore the composition - both geographical and social - of the city, and the idea of subversives in Santiago. In this chapter Craib discusses different reactions towards those considered subversive, and the decisions taken by the government. In the process of investigating the subversives, a special prosecutor was appointed and given broad powers. The chapter deals with the ways in which subversives would be identified, and how those systems were developed and functioned. Here Craib is able to expand on how ideas regarding the identification of criminals were developed abroad and then applied in Chile, whilst also outlining the surveillance regime applied to those considered dangerous.

Chapter four explores the time Gómez Rojas spent in prison, discussing his experience in jail and providing a brief history of the prison in Santiago, allowing the reader to understand the conditions Gómez Rojas faced. In the chapter, Craib also discusses the life of the poet and his work, building on some of the themes developed in previous chapters.

One of the first things to note is the connections that this book (which focuses on Chile) has with Craib's book on Mexico, Cartographic Mexico: a History of State Fixations and Fugitive Landscapes.(1) In this study we see many of the ideas about space that are also addressed and developed in The Cry of the Renegade . In Cartographic Mexico, Raymond Craib analysed the role maps played in the construction of the modern Mexican state. However, the study looks beyond maps, analysing the everyday processes that generated them. In this book, Craib is able to show how map making and surveying are not mere technical procedures, but reflections of social and political practices where different actors come into play. In Cry of the Renegade, Craib explores similar ideas of space, in terms of its production, both physical and imagined, through exploring the writings and political activities of Gómez Rojas and friends, as well as the space where they socialised and worked. Moreover, they shared memories, which were rooted on the everyday practices that they engaged in together. As stated by the author, 'this is story of individuals and the collective struggles they waged, futures they imagined, and worlds they occupied' (p. 13). In this sense, the main contribution of the book is its ideas about how these networks function, and the clear map of those networks it provides.

It is crucial to think about the role that ideas and the construction of knowledge play in The Cry of the Renegade 
, and how those connect with ideas of power. In much of his writing Michel Foucault explores ideas of knowledge and power, highlighting how knowledge provides a connection between space and power. In the case of his book, Craib explores different types of knowledge: what Craib calls a 'capacious left' (meaning an inclusive and pluralistic left), governmental, conservative and nationalist, among others. These different forms of knowledges represent different worldviews and the book shows the reader how they encounter and clash with one another. In these encounters, ideas of what constitutes a citizen, the state, freedom of speech, criminality, will be redefined from the standpoints of these particular groups and their knowledge. This idea goes hand in hand with Foucault's notion that the researcher needs to consider other forms of domination, such as administration, politics, and relations of power, which are tightly bound by ideas of space, such as region and territory. A clear example of the latter can be seen throughout The Cry of the Renegade when Craib is able to highlight how the police and the government developed systems of identification of people (connecting to transnational ideas of control and physical identification), which also had a geographical expression in maps, giving a clear idea of where those considered subversives lived their lives.

Another theme that appears throughout the book is that of the construction of the idea of the subversive. The context to understand the latter is twofold: on one hand, the anger towards pro-Peruvian sentiment; and on the other, ideas on anarchism and communism. Anti-Peruvian ideas played an active role in determining who belongs where, as well as who was a good citizen or a bad one. In this sense, supporting pro-Peruvian ideals put you in the position of the outsider, of the other, as much as being a foreigner in 1920s Chile did. As regards the second aspect, Craib attempts to discover what subversion means in a moment in time. He explores the way those in power use certain terms, such as 'anarchist' and 'subversive', to delegitimise political voices that are perceived as opposing the political order, and to legitimise their own political project. In this context, the people deemed 'subversive' were identified as nationless. Thus, language plays a key role in constructing political identities, both of themselves and of the other. Anarchism is an idea that moves beyond politics, also signifying a mode of human behaviour. In this sense, there is not one way of being an anarchist, but a range of positions within that political spectrum. Moreover, these were not exclusive perspectives but, as mentioned before, constantly moving and changing depending on who is constructing meaning. In many ways, ideas of the other and the foreign will be tied up with those perceived to follow ideas that were not considered Chilean (or pro-Chile). This is particularly meaningful when, for some conservative groups and part of the government, FECh became an internal enemy due to its political project, links to international ideas and movements, as well as those who were part of the federation.(2) Their political position and discourse (both in speeches and publications) also rendered the person a subversive and an outsider. Thus, one of the questions that guides this book is that of the identity of the subversive and how it is constructed.

The Cry of the Renegade also deals with issues of memory and remembrance. By situating Gómez Rojas's story in its proper historiographical context, Craib attempts to make the reader rethink the figure of this poet as a man who was not a martyr, but part of a wider group of people who were also pursued and persecuted. Moreover, what the author is trying to do is to bring in the story of those who were pursuers and prosecutors, presenting the experience of repression from both sides. Other historians have attempted to do this when dealing with memory, for instance Steve Stern in his trilogy The Memory Box of Pinochet's Chile (3), which truly attempts to address ideas of collective memory.

Finally, The Cry of the Renegade puts forward a series of transnational aspects that are fundamental to understanding the networks of ideas and people Craib is studying. The author focuses on groups who identify with international ideas, such as communists and anarchists, groups who believed in the idea of being citizens of the world. He also provides connections to wider ideas on criminality and how a science to study and identify criminality was being developed. He also looks at how ideas moved through networks and migrants who settled, as well as through newspapers and knowledge. The link Craib makes with the transnational aspect takes the book from the details of what was happening in Santiago in a particular moments in time and puts it in context, giving a sense and perspective to the decision making of the authorities and the discourses and speeches of those considered subversive.

One possible issue with the book is that it mirrors the centralism of Chile, in the sense that it is a book whose 
historical actors all live in Santiago. It is hard to overcome this problem, which is so tied up in the political and economic structure of the country. However, the author does provide a warning regarding this and, as stated before, is able to put some ideas in a transnational context. This situates The Cry of the Renegade as a microhistory of Chile that works, allowing the reader to make connections with the current situation of the country in a way that, at times, can be uncomfortable due to how little has changed.

\section{Other reviews:}

Anarkismo

https://www.anarkismo.net/article/30348 [2]

Source URL:https://reviews.history.ac.uk/review/2128

\section{Links}

[1] https://reviews.history.ac.uk/item/264290 [2] https://www.anarkismo.net/article/30348 